\title{
Persistent left superior vena cava and absence of innominate vein during coronary artery bypass surgery
}

\author{
Jih Huei Tan, ${ }^{1}$ Zi Qin $\mathrm{Ng}^{2,3}$ Simon Vendargon ${ }^{1}$
}

'Department of Cardiothoracic Surgery, Hospital Sultanah Aminah, Johor Bahru, Malaysia ${ }^{2}$ Royal Perth Hospital, Perth, Western Australia, Australia ${ }^{3}$ Department of General Surgery, St John of God Midland Public and Private Hospitals, Midland Western Australia, Australia

\section{Correspondence to} Dr Zi Qin Ng,

kentng@hotmail.co.uk

Accepted 11 April 2018

\section{DESCRIPTION}

A 56-year-old man presented with acute left-sided chest pain at rest with associated dyspnoea. His heart rate was 35 beats/min and ECG revealed a complete heart block. A temporary cardiac pacing was implemented on the right side via transcutaneous leads. He was also diagnosed with non-ST elevation myocardial infarction due to raised cardiac enzymes and was managed with medical therapy. The pacemaker was removed after 3 days when he reverted to sinus rhythm. Coronary angiogram was subsequently performed and revealed a critically obstructed triple coronary vessel disease. Echocardiography revealed an ejection fraction of $40 \%$, competent valves and normal chamber size. Coronary artery bypass graft (CABG) surgery was performed via median sternotomy. Interestingly, there were no innominate veins identified intraoperatively and a dilated coronary sinus was seen on transoesophageal echocardiography. Cardiopulmonary bypass was initiated following aortic and two-stage right atrial venous cannulation. The heart was cooled and intentionally stopped by antegrade cardioplegia. On lifting the heart, a left superior vena cava was identified adjacent to the left atrial appendage (figure 1). Two vein grafts were grafted to the posterior descending artery and distal left circumflex. The left internal mammary artery harvested was grafted to left anterior descending artery.

Persistent left superior vena cava (PLSVC) is a rare congenital vascular anomaly due to the failure of left superior cardinal vein caudal to the innominate vein to regress in utero. ${ }^{12}$ The incidence of PLSVC is $0.3 \%$. It is usually asymptomatic and is

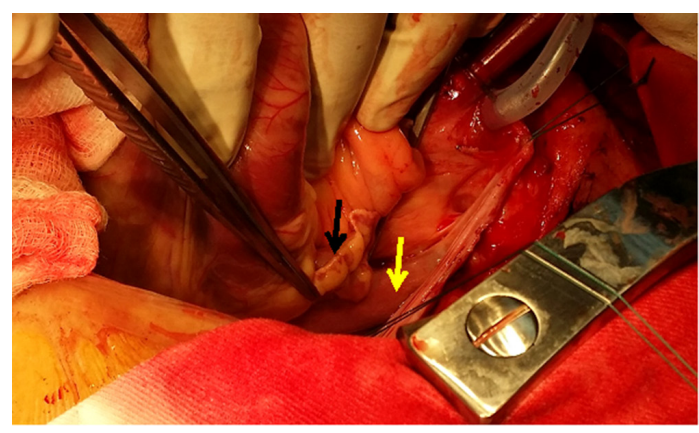

Figure 1 Picture showing tip of the forceps pointing on the left superior vena cava (yellow arrow) with the left atrial appendage (black arrow) just adjacent to it.

\section{Learning points}

Persistent left superior vena cava (PLSVC) has no dire consequences in most coronary artery bypass graft or valve surgery with single caval cannulation. However, its significance when inserting a pacemaker or giving cardioplegia should be taken into consideration pre-emptively.

- An enlarged and dilated coronary sinus on echocardiography should serve as an indicator to suspect PLSVC.

an incidental finding on cardiac catheterisation or echocardiography. ${ }^{3}$ Two-thirds of such case is associated with the absence of innominate vein. ${ }^{1}$ In rare cases, the left SVC drains into left atrium which is usually associated with some desaturation and possible paradoxical embolism.

For patients undergoing CABG surgery, the recognition or failure to recognise the left SVC would be of no dire consequences. It is true also for most valve surgery which is performed with a single venous cannula. The PLSVC is important when bicaval cannulation is necessary and the right atrium is explored. In that instance, a third caval cannulation will be required.

In patients with PLSVC, placement of a transvenous permanent pacemaker is technically more difficult. Fortunately, in this case the patient reverted to sinus rhythm successfully with transcutaneous pacing. However, it also precluded the opportunity for us to identify this vascular anomaly prior to cardiac catheterisation. If transvenous pacing was required, it may still be straightforward as the right SVC is present. Nonetheless, $10 \%$ of cases with absent right SVC may lead to the advancement of catheter through left SVC, left atrium, coronary sinus, right atrium and into right ventricle. To avoid the difficult course and potential complication, implanting lead at left atrial or ventricle has been reported.

Another practical issue of left SVC draining into coronary sinus is the difficulty to achieve retrograde cardioplegia. The options for retrograde cardioplegia in this case include placing a sucker in the coronary sinus, setting up a separate vent up the coronary sinus and snaring it off, separating cannulation (with three venous cannulae), or simply snaring it off during the procedure. 
Contributors JHT designed the study, collected and analysed the data, drafted the article and approved the final version of the article to be published. ZQN analysed the data, revised the article and approved the final version of the article to be published. SV codesigned the study, analysed the data, critically reviewed the article, supervised the study and approved the final version of the article to be published.

Funding The authors have not declared a specific grant for this research from any funding agency in the public, commercial or not-for-profit sectors.

Competing interests None declared.

Patient consent Obtained.

Provenance and peer review Not commissioned; externally peer reviewed.
(C) BMJ Publishing Group Ltd (unless otherwise stated in the text of the article) 2018. All rights reserved. No commercial use is permitted unless otherwise expressly granted.

\section{REFERENCES}

1 Goyal SK, Punnam SR, Verma G, et al. Persistent left superior vena cava: a case report and review of literature. Cardiovasc Ultrasound 2008;6:50.

2 Paval J, Nayak S. A persistent left superior vena cava. Singapore Med J 2007;48:e90-3.

3 Akpinar I, Sayin MR, Karabag T, et al. Persistent left superior vena cava, absence of the innominate vein, and upper sinus venosus defect : a rare anomaly detected using bubbles. Herz 2013;38:317-20.

Copyright 2018 BMJ Publishing Group. All rights reserved. For permission to reuse any of this content visit http://group.bmj.com/group/rights-licensing/permissions.

BMJ Case Report Fellows may re-use this article for personal use and teaching without any further permission.

Become a Fellow of BMJ Case Reports today and you can:

- Submit as many cases as you like

- Enjoy fast sympathetic peer review and rapid publication of accepted articles

- Access all the published articles

Re-use any of the published material for personal use and teaching without further permission

For information on Institutional Fellowships contact consortiasales@bmjgroup.com

Visit casereports.bmj.com for more articles like this and to become a Fellow 